\title{
ポリエステルフィルムの分子運動に及ぼす 染料および水分の影響
}

\author{
昭和女子大学短期大学部 戸田 玉子 \\ 東京都立大学工学部 吉田 博久・飛田 満彦
}

\section{EFFECTS OF DYE AND MOISTURE ON MOLECULAR MOTIONS OF POLYESTER FILM}

\author{
Tamako Toda ${ }^{* 1}$, Hirohisa Yoshida*2, and Mitsuhiko Hida ${ }^{* 2}$ \\ * 1 Showa Women's Junior College, 1-7.57 Taishido Setagaya-ku, Tokyo, 154 Japan \\ *2 Department of Industrial Chemistry, Facuity of Technology, Tokyo Metroplitan \\ University 2-1-1 Fukazawa, Setagaya-ku, Tokyo, 158 Japan
}

\begin{abstract}
The effect of dye and water on the molecular motions of poly (ethylene terephthalate) (PET) was investigated by dynamic viscoelastic measurements and thermal analysis of dyed PET films. Both $\alpha$ and $\beta$ loss modulus peaks of dry films shifted to lower temperature side with the increase of dye concen. tration, accompanied by a decrease of their apparent activation energy. The results suggested that dye molecules in the films enhanced the segmental mobility of PET as a result of plasticizing effect. The num. ber of segments per unit cross section derived from the relaxation intensity of $\beta$ dispersion, which was associated with local mode relaxation of PET, depended on dye concentration in the films. It is expected that higher dye concentration brings about a different mode of dye adsorption in PET substrates. The apparent activation energy of $\alpha$ dispersion due to glass transition of PET decreased markedly in the presence of water. The segmental mobility of PET chains seem to be much sensitive to moisture content in the film as compared with plasticizing effects by dye molecules.
\end{abstract}

(Received March 22, 1991)

\section{1. 緒㝘}

我々のこれまでの高分子基質中の蛍光增白染料の光退 色举動の研究 $[1,2]$ やポリエステル(PET)フィルム中 の Crystal Violet Chloride (CV)の光退色に関する研究 〔3-6]から，退色時に拁ける基翼の微細棈造に起因する 染料の分散状態が退色挙動に影翼するとともに，基質の 分子連動が染料の分散状態に深く関わる可能性が考えら れた。

ところで高分子基質中の染料の分散状態については， これまでに直接，間接的に測定が行われ検討されてい 而。セルロースフィルム中の染料の染着状態について E. I. Valko (7) は X 楾回折から, L.W.Weissbein b (8) は電子顕微鏡による観察から検討を行っている。また Giles ら９（柾水性基質中のアントラキノン系分散染
料の短波長と長波長の吸収バンドの強度比に湄度依存性 があり集合体が形成されると考察しているが，D。 Wegerle〔10]は同栏な実験を行った結果，PET中では 染料は会合していないと報告している。筆者ら[11]は アクリジンオレンジによる染色緎維断面の顕微分光光度 計による吸收スペクトルの湘定から，PET 较維中にお いて染料が単量体挹よび集合体として存在することを報 告した。藤野ら [12]は Congo Redを収着させたPVA フィルムのタリープを測定し，高收着量の場合には染䊅 相互間で会合が起こると報告している。

一方，高分子中の染料分子と高分子鎖の分子運動との 関係については，こ扎までに离分子基質中に㧍ける染料 の搪散性と高分子の転移現象との関係から㭲討されてい る。Dumbletonら（13) はPET 䋐維中に扔ける分散染料 の拡散性と染色条件下でのPET 繊維の E" との関係を模 
討し，高分子鎖のセクメント運動が染料の掂散に影響す ることを報告している。また森田ら〔14〕は染色系での PET 中における分散染料の分子の大きさおよび应散係 数と拡散の活性化エネルギーおよび拡散に現れる転移温 度との相互作用を検討し，PETの分子運動々染料の搪 散が密接に関係していると報告している。一方，PET フィルム中の分散染料の昇華搪散の研究から, Ito ら 〔15〕は拡散係数のアレニゥスプロットが $2-4$ の屈折点 を持つ直線であり，屈折点は高分子の運動が变化する転 移点であるとしている。これに対して酒井ら〔16〕は搪 散保数の温度依存性はWLF 型に適合し，ガラス転移点 から融点の間に別の転移点は存在しないとしている。ま た高分子中の染料の拡散に有効な自由体積は，染料の大 きさや染料と高分子との相互作用などによって決まり， 搪散速度を支配するとしている。

本研究では，染料の光退色挙動と基質の分子運動との 関係を明らかにしていくために，染料が存在する基質の 微細構造を検討することを目的とし，水分率，染料漸度 の異なる PETフィルムのガラス転移温度, 動的粘弾性 を測定することにより PET の分子運動に及ぼす染料お よび水分の影響を検討した。

\section{2. 実佒}

\section{1 試料}

染料住 Crystal Violet Chloride (C. I. Basic Violet 3'GR，関東化学工業製)を用いた。使用したPETフィ ルム(帝人製)は膜厚 $9 \mu$ の二軸延伸フィルムで巻積し $130^{\circ} \mathrm{C}$ 水中で 1 時間熱処理を行った。

\section{2 染 色}

上記フィルムを $1.23 \times 10^{-5}, 2.11 \times 10^{-5}, 122.85 \times$ $10^{-5} \mathrm{~mol} / \mathrm{L}$ 水溶液中, 浴比 $1: 200, \mathrm{pH}=5,130^{\circ} \mathrm{C}$ で 1 時間染色を行い， $0.31 \times 10^{-5}, 0.57 \times 10^{-5}, 2.05 \times 10^{-5}$ $\mathrm{mol} / \mathrm{g} . \mathrm{film}$ (フィルムの吸光度はそれぞれ0.5，1.0, 3.0)の涱度を得た。

未染色拈よび 3 湄度の染色フィルムの広角 X 線回折 測定から染料㬊度により結晶化度に差異がないことを確 認した。結晶化度は60-64\%であった。

\section{3 試料の摆湿と水分事}

未染色および染色した絶乾試料を $20^{\circ} \mathrm{C} ， 31 ， 52$ ， 98\%RHのデシケータ中で恒量になるまで調湿した後、 試料の水分率を計算した。

\subsection{DSCによる Tgの測定}

試料の Tgはセイコー電子工業製熱分析システム SSC5000に示差走查熱量計 SEIKO DSC 200を接続して測 定した。絶乾および98\%RHのもとでの調湿フィルムを DSC 用密閉アルミパン中にパッキングした後秤量し，
昇温速度 $10^{\circ} \mathrm{C} / \mathrm{min}$, 咥素需囲気中で測定を行った。測 定後，パンに穴をあけて $300^{\circ} \mathrm{C}$ まで昇温し測定前後の重 量より試料の正硴な水分率を求めた。

\section{5 的粘弾性の测定}

乾燥試料の動的粘弾性測定は, 粘弾性スペクトルメー タSDM 5600(セイコー電子工業製)にテンションモジュ ール DMS 200 を接続して引張モードで周波数 2-20 $\mathrm{Hz}$ ，昇温速度 $2^{\circ} \mathrm{C} / \mathrm{min}$, 窒素雲囲気中で行った。湿潤 試料の場合には，98\%RHで調湿した試料を動的熱機械 測定装置 SEIKO TMA/SS 300(セイコー電子工業製)を 用い，測定部を水に浸漬した状態で周波数 $0.001-1$

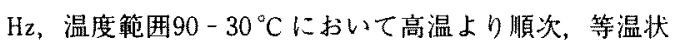
態(設定温度士0.1 $\left.{ }^{\circ} \mathrm{C}\right)$ で測定した。

\section{3. 結果と考察}

\section{$3.1 \mathrm{PET}$ フィルムの動的粘弾性に及ぼす染料の影響}

図1は末染色拉よび染色(吸光度3.0) PET フィルムの 動的粘弾性スペクトルである。損失弾性率 $\left(E^{\prime \prime}\right)$ 曲線で は低温と高温部に二つのピークが認められる。低温部の ピークは主鎖の局所的な運動によるß分散であり，高温 部におけるピークは非晶領域内の主鎖のミクロブラウン 運動に起因する $\alpha$ 分散である[17]。

動的粘弾性スペクトルに対する染料の影響は， $\alpha$ 分散 よりも $\beta$ 分散に顥著に現れている。染料濃度が高くなる と $\beta$ 分散は低温側に移行するとともにその幅が狭くな

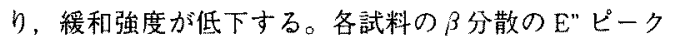
温度 $\left(T_{\beta}\right)$ と分散ピーク温度の測定周波数依存性から得ら れる $\beta$ 分散の見掛けの活性化エネルギー $\left(\Delta \mathrm{H}_{\beta}\right)$ を表 1 に 示す。染料濃度が增加すると $\mathrm{T}_{\beta}$ は低くなるが， $\Delta \mathrm{H}_{\beta}$ は 染色試料では染料濃度の增加にともない小さくなるもの の，低濃度試料の值は未染色試料の值よりも大きい。 $\beta$

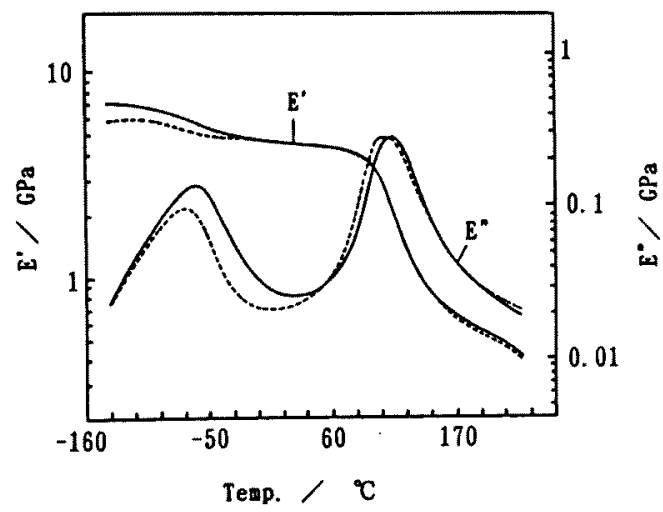

Fig. 1. Dynamic viscoelastic spectra of PET films undyed film ….. ; dyed film (Abs. 3.0). 
Table $1 E^{n}$ Peak Temperature and Aparrent Activation Energy of $\beta$ Dispersion

\begin{tabular}{ccc}
\hline Absorbance & $\mathrm{T}_{\beta}{ }^{\circ} \mathrm{C}$ & $\Delta \mathrm{H}_{\beta} / \mathrm{kJ} \cdot \mathrm{mol}^{-1}$ \\
\hline 0 & -63 & 60 \\
0.5 & -68 & 84 \\
1.0 & -69 & 75 \\
3.0 & -79 & 42 \\
\hline
\end{tabular}

分散に㷌属される非晶領域の局所モード緩和は繰り返し 単位が数個以下の種々の緩和時間を持つ主鎖の分子運動 で椿成されていると考えられている。従って，分散ピー クが染料濃度の增加にともなって高温側から隇少してい るという実験結果は，長い緩和時間の分子運動が阻害さ れていることを示している。

Yoshida, Kobayashi [18]はエンタルピー綗和過程に 対する p-アミノアゾベンゼンとC.I. Disperse Yellow 7 の二種類の染料の影䇾を検討し，染料濃度が增加すると Tgが低下し，エンタルピー緩和時間は長くなり，兒掛 けの活性化エネルギーは大きくなると報告している。エ ンタルピー楥和に関与する分子運動は $\beta$ 分散の祄象とな 万分子運動よりも大きな規模の運動であるものの，エン タルピー緩和時間はガラス状態での主鎖の分子運動の緩 和時閏を反映している $[19] 。$ 吸着した染料がガラス状 態での緩和時間の長い主鎖の運動を妨げるという点で本 研究での結果とYoshida, Kobayashi の結果とは定性的 に一致する。しかし高濃度に执いては、エンタルピー緩 和では染料は分子運動を阻害するのに対し， $\beta$ 分散では $\Delta H_{\beta} 、 T_{\beta}$ は低下L，見掛け上，運動が促進されている。 これは対象とする分子運動の緩和時間が異なることと, 使用した染料の形状ならびに高濃度での染料の凝集状態 の遠いなどによって，高濃度領域での差が生じたと考え られる。

以上述べてきたようにガフス状態での非晶領域におけ る分子鎖の運動に対する染料の影㸷が濃度によって異な ることから，染料濃度が高くなるのにともない系の鼠由 体積は增えるが，その増加の程度は离染料濃度で異なる ことが尔想される。このことは，PETフィルム中での 染着状態が高染料濃度で忧变化する可能性が考えられ b。

そこで分散の緩和強度から単位断面積当りのセグメ ント数を求め, 各染料蕽度の染着状態を検討した。 $\beta$ 分

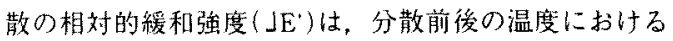
動的弹性率を各々 $\mathrm{E}^{\prime}(\infty), \mathrm{E}^{\prime}(0)$ と才ると次式で表すこ とができる。

$$
\lrcorner E^{\prime}=\frac{E^{\prime}(\infty)-E^{\prime}(0)}{E^{\prime}(\infty)}
$$

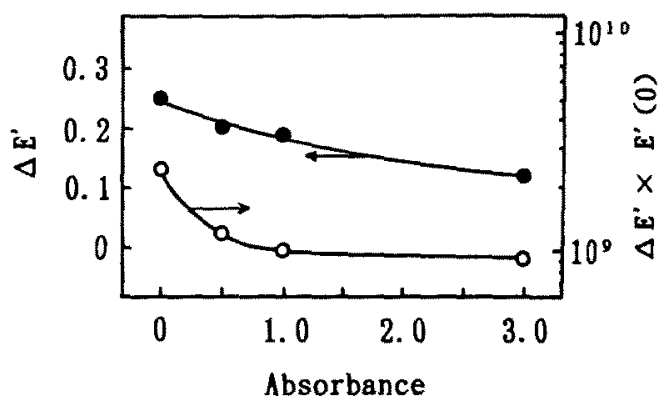

Fig. 2. Effect of dye concentration on relaxation in tensity of $\beta$ dispersion and on the number of segments per cross section: $: \Delta E^{\prime}, O ; J E^{\prime} \times E^{\prime}(0)$.

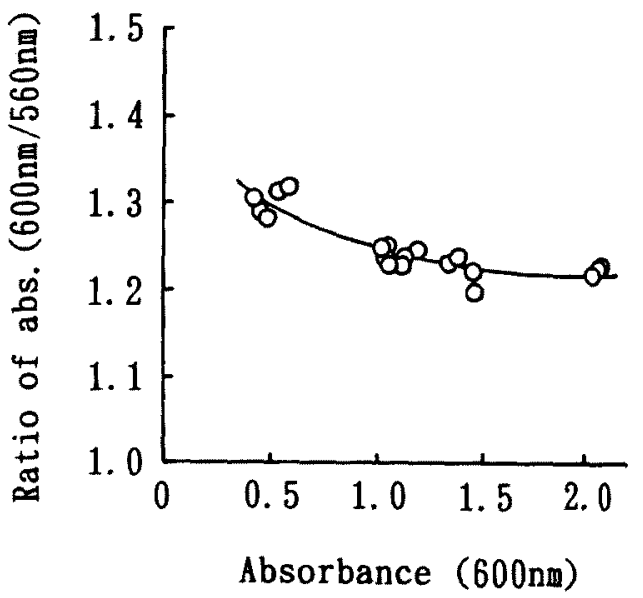

Fig. 3. Effect of dye concentration on ratio of absorb. ances at $600 \mathrm{~nm}$ and $560 \mathrm{~nm}$.

更に，分子鎖の挨り運動の摇らぎを考慮すると，緩和 弾性率は次の式で記述することができる $(20] 。$

$$
\Delta E^{\prime} \simeq \frac{n A k T}{E^{\prime}(0)}
$$

ここでnは試料の単位断面積当りの運動七グメント 数，Aは運動セグメントの形状に関する係数，kはボル ッマン定数, Tは温度である。図 2 に $\times E^{\prime}(0)$ の染料婊度に対するプロットを示した。染料㵊 度の増加にともなって J $\mathrm{E}^{\prime}$ 书よび運動セグメント数に比 例する JE'XE'(0)は減少するが，高濃度側ではほぼ一 定の值を示す。高濃度では染料が集合して存在し，低济 度において染料が単分子状態で染着する場合よりも自由 体積の增加に寄与する程度が小さいと考えられる。この ことは先に述べたガラス状態での高分子主鎖の運動に対 する染料の效果が単分子状態と会合状態とでは異なるこ とを示唆している。 
$\mathrm{CV}$ の吸取スペクトルには600 nm 付近に振動モードに よる二つの吸収バンドがあり，基質中あるいは溶液中で 染料が単分子分散している場合には，長波長側の吸収バ ンドと低波長側の吸収バンドの比が約1.3となり，染料 が集合するにともない1.3より小さい値となることが報 告されている(21)。図3は染色PET フィルムについて $600 \mathrm{~nm}$ と $560 \mathrm{~nm}$ の吸収バンドの強度比と濃度の関倸を 示したものである。濃度が增加するにともないこの比は わずかに低下し，染料の一部が集合しているものと考え られる。この結果は緩和強度から求めた単位断面積当り の七グメント数と濃度の関倸に上く対応している。

染料試料の $\alpha$ 分散については㘠 1 に示したように未染 色試料に比べわずかに低温側に移行している。

Table 2 E" Peak Temperature and Aparrent Activation Energy of $\alpha$ Dispersion

\begin{tabular}{ccc}
\hline Absorbance & $\mathrm{T}_{\alpha} /{ }^{\circ} \mathrm{C}$ & $\Delta \mathrm{H}_{\alpha} / \mathrm{kJ} \cdot \mathrm{mol}^{-1}$ \\
\hline 0 & 111 & 410 \\
0.5 & 109 & 330 \\
1.0 & 109 & 350 \\
3.0 & 108 & 348 \\
\hline
\end{tabular}

表 2 に各染料濃度における $\alpha$ 分散の E”ピーク温度 $\left(\mathrm{T}_{\alpha}\right)$ およ゙見掛けの活性化エネルギー $\left(\Delta \mathrm{H}_{\alpha}\right)$ をまとて 示した。 $\mathrm{T}_{\boldsymbol{\alpha}}$ と $\Delta \mathrm{H}_{\alpha}$ の濃度依存性は良く対応しており， $\mathrm{T}_{a}$ と $\Delta \mathrm{H}_{a}$ は濃度の增加とともに隇少している。これは 染料が PET の非晶領域にあって分子鎖間のファンデル ワールス結合を切断し，分子鎖の間隔を広げて分子連動 に影響を与え，濃度の増加とともに主鎖のミクロブラウ ン運動が起こり易くなることを示している。

\subsection{PET フィルムのガラス転移温度に及ぼす染料およ び吸着水分の影䈏}

一般に結晶性 PETフィルムのガラス転移温度をDSC により測定することは難しいが，本研究で用いたPET フィルムではガラス転移温度 $\left(\mathrm{T}_{\mathrm{g}}\right)$ における基線の明瞭 なずれは少ないものの，いずれの染料濃度の場合にも $\mathrm{Tg}$ は認められ，染料濃度の增加とともに $\mathrm{Tg}$ が低温側 に移行することが認められた。

図 4 は DSC曲線からもとめた Tgと染料濃度の関係 を示したものである。濃度が增加するに従いTgが低下 し, 吸光度3.0では未染色に此べ約 $10^{\circ} \mathrm{C}$ の低下が認めら れる。この傾向は温度差は異なるものの $\alpha$ 分散の $\mathrm{E}^{\prime} ヒ ゚$ 一タ温度 T。の嶩度依存性に良く対応している。また $98 \%$ RH における湿閏試料と乾燥試料の結果から水分の 存在によりフィルムの $\mathrm{Tg}$ が低温側に移行するのがわか る。图 5 に $\mathrm{Tg}$ とフィルムの水分率の関係を示した。水

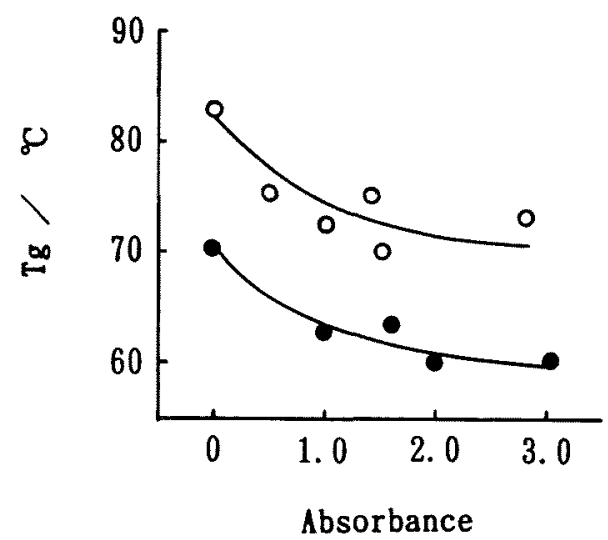

Fig. 4. Relationship between $\mathrm{Tg}$ and dye concentration : $O$; under dry condition, $O$; under wet condition (98\%RH).

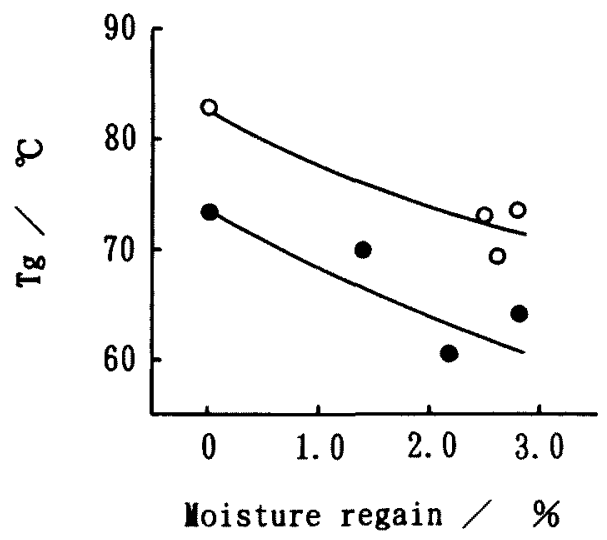

Fig. 5. Relationship between $\mathrm{Tg}$ and moisture regain : O; undyed film. : dyed film (Abs. 3.0).

分率の堌加とともに $\mathrm{Tg}$ が低下し，乾燥試料に对して水 分率的 $3 \%$ 湿潤試料で $10^{\circ} \mathrm{C}$ 以上の低下が認められ る。水分の影響については Dumbleton ら (13) は種々の 温度で熱処理したPET 䋐維の E”を乾嬠および湿閏状態 で測定し，水分の影響を検討している。その中で本研究

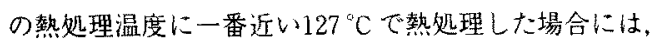
$\mathrm{E}^{\prime \prime}$ ピーク温度が乾燥状態で $103^{\circ} \mathrm{C}$, 湿潤状態で $85^{\circ} \mathrm{C}$ と なり，水分の存在によりガラス転移温度が低下すると報 告している。また Hatakeyama ら (22) も非結晶性PET フィルムでは微量な水分の存在により $\mathrm{Tg}$ が低下すると の結果を得ている。これらは我々の得た結果と良く一致 している。

PETは踈水性であるため吸湿性が低いが，イオン性 の染料である CV で染色するとフィルムの吸湿性が変化 し Tgへの影翠の可能性が考えられる。そこで相对湿度 
Table 3 Moisture regain of PET film at $20^{\circ} \mathrm{C}$

\begin{tabular}{cccc}
\hline & \multicolumn{3}{c}{ moisture regain/\% } \\
\cline { 2 - 4 } & \multicolumn{3}{c}{ relative humidity/\%RH } \\
& 31 & 52 & 98 \\
\hline 0 & 0.06 & 0.54 & 1.11 \\
0.5 & 0.08 & 0.57 & 1.30 \\
1.0 & 0.42 & 0.67 & 1.70 \\
3.0 & 0.67 & 1.13 & 2.43 \\
\hline
\end{tabular}
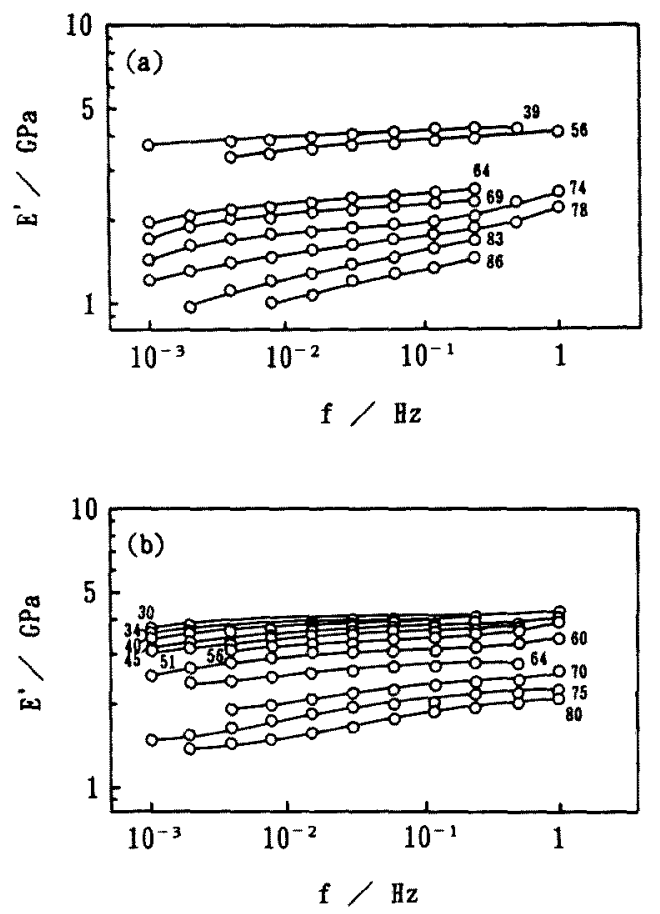

Fig. 6. Frequency dependence of dynamic modulus E' for $\alpha$ dispersion of wet PET film at various temperatures: (a) undyed film, (b) dyed film (Abs. 3.0).

と染着量の異なるフィルムの水分率を測定し、その結果

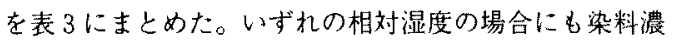
度の増加とともに水分率が高くなり，フィルムの吸湿能 力が问上しているのがわかる。しかし図 5 に示したよう に，Tgに対する吸着水の影響は染色フィルムの方が末 染色フィルムの場合よりわずかに大きい程度である。以 上のように微量な水分の存在が分子鎖の連動を活発に

し，Tgを低下させることが明らかとなった。

更に、水分の影䈉を詳細に検討するために湿潤時にお ける動的粘弾性を測定した。図6(a)，(b)はそれぞれ湿

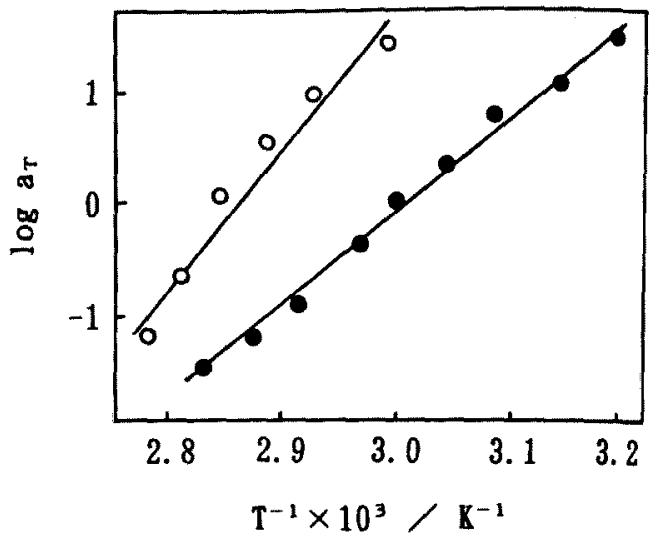

Fig. 7. Arrhenius plots of shift factor for a dispersion of wet PET film : O undyed film, dyed film (Abs. 3.0 ).

閏末染色フィルム，湿潤染色(吸光度 3.0 ) フィルムのa 分散に扔ける譻蔵弾性率( $\left.\mathrm{E}^{\prime}\right)$ の各温度に扔ける周波数依 存性を示したものである。これらを重ね合わせた合成曲 線より各温度におけるシフトファクタ一、开を求めた。 基準温度はDSC 测定で得られた $\mathrm{Tg}$ とし，末染色試料

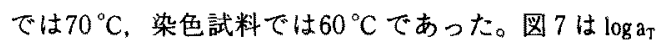

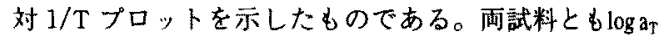
の温度依存性は，Tg を基準温度としたWLF

$$
\log \mathrm{a}_{\mathrm{T}}=\frac{-\mathrm{C}_{1}(\mathrm{~T}-\mathrm{Tg})}{\mathrm{C}_{2}+(\mathrm{T}-\mathrm{Tg})}
$$

式で表すことができる。染色フィルムの場合には， $\mathrm{C}_{1}=$ $15, \mathrm{C}_{2}=32$ であるのに対し、未染色フィルムでは $\mathrm{C}_{1}=$ $7, C_{2}=12$ となり,一般に知られている值 $\left(C_{1}=17.44\right.$,

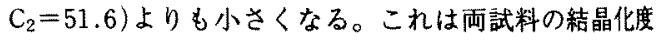
が高いことが関係していると考えられる。 $\log a_{\mathrm{T}}$ の温度 依存性がWLF 式で記述できることから，ここで観測さ れた緩和現象がガラス転移のみの単一なメカニズムによ るものと考えられる。従って，测定した温度領域での7 レニウスプロットの平均の傾きから湿潤試料の見掛计の 活性化工ネルギーが求められる。前述の乾燥試料の活性 化エネルギーと比較すると，未染色の場合，乾燥試料で $\Delta \mathrm{H}_{a}: 410 \mathrm{~kJ} \cdot \mathrm{mol}^{-1}$, 湿閏試料で $85 \mathrm{~kJ} \cdot \mathrm{mol}^{-1}$, 染色(财光 度3.0)の場合, 乾燥試料で $\Delta \mathrm{H}_{\alpha}: 348 \mathrm{~kJ} \cdot \mathrm{mol}^{-1}$, 湿阔陚 料で $65 \mathrm{~kJ} \cdot \mathrm{mol}^{-1}$ となる。水分が存在すると活性化工六儿 ギーが著しく低下することがわかり，その効果は染料の 場合の数倍に及んでいる。また，染色フィルムの場合に は末染色に此較して水分の存在により活性化工ネルギ一 の低下の程度が幾分大きいが，これは染料の吸湿性が影 辢しているものと考えられる。 
以上のことから染料および吸着水分が基質の分子連動

を起こり易くし，染料の分散状態に影響を及ほすことが 明らかになるとともに，染料や办分の拡散にも影幚する 可能性が示腹された。また，一般に高分子に対する可塑 化効果は, 低分子物が $1 \mathrm{wt} \%$ 以上含有されないと出現 しないとされているが, 本研究では0.13-0.80 wt\%で 可塑化效果が認められ，通常の可塑剂の場合上りは低䟴 度で効果が出現することが明らかとなった。

付記：DMSの測定にご協力いただきましたセイコー 電子工業株式会社, 大久保信明氏ならびに PET フィル 么を提供していただきました帝人株式会社に感謝いたし ます。

\section{文献}

1. 佐久間裕子, 飛田满彦, 矢部章彦, 工業化学雑誌, 73, $756(1970)$

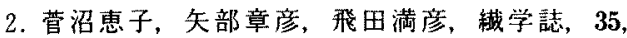
T-388 (1979)

3. 戸田玉子，飛田満彦，第30回染色化学討論会講演要 旨集, p. 84 (1988)

4. T. Toda and Hida Mitsuhiko, Sen'i Gakkaishi, 46 $155(1990)$

5，戸田玉子，飛田満彦，由島正弘，第32回染色化学討 諭会講演要旨集, p. 5 (1990)

6, 万田玉子，飛田満彦，第32回染色化学討諭会講演要 旨集, p. 31 （1990）

7. E. I. Valko, J. Am. Chem. Soc., 63, 1433 (1941)

8. L. Weissbein and G. E. Coven, Text. Res. J., 30, 58
(1960)

9. C. H. Giles and C. D. Shah, Trans. Faraday Soc, 65, 2508 (1969)

10. D. Wegerle, J. Soc. Diers \& Colourists. 89, 54 (1973)

11. T. Ohtsu (Toda), K. Nishida, K. Nagumo and K. Tsuda, Colloid \& Pohm. Sci., 252, 377 (1974)

12. 藤野清久, 藤本典秀, 緎学誌, 15, 76 (1959)

13. J. H. Dumbleton, J. P. Bell and T. Murayama, $J$. tppl. Polym. Sci. 12, 2491 (1968)

14. 森田全三, 小山和夫, 飯島俊郎, 日化誌, No. 8, $1522(1972)$

15. I. Ito, S. Okajima and F. Shibata, $J$ Appl. Polym. Sci., 14, $551(1970)$

16. 酒井豊子, 宮坂啓象, 石川欣造, 䋐学誌, 33 , $\mathrm{T}-571$ (1974)

17. M. Ito, S. Nakatani, A. Gokan and K. Tanaka, J. Polym. Sci. Polym. Phys., 15, 605 (1977)

18. Yoshida and Y. Kobayashi, Sen $\ddot{i}$ Gakkaishi., 37, T$458(1981)$

19. 吉田博久, 熱測定, 13, 191 (1986)

20. K. Yamafuji and Y. Ishida, Kolloid-Z.. 183, 15 (1960)

21. R. Nakamura and M. Hida, Sen i Gakkaishi., 39, T. 125 (1983)

22. T. Hatakeyama and H. Hatakeyama, Sen $i$ Gakkaishi., 39, T.461 (1983) 